\title{
Het nieuwe normaal
}

\section{JOB VAN AMERONGEN}

$\mathrm{D}$ e zusters en broeders werken dezer dagen in cohort en de huiskamers, normaal het epicentrum van ons verpleeghuis, zijn leeg en verlaten. De kalenders staan nog op 17 maart.

We gaan elke dag van deur tot deur. Op visite bij de eenzame bewoner. Om te helpen met wassen en aankleden. Om eten en drinken te brengen. En om aanwezig te zijn bij het sterven. Ook dat. Soms treffen we een bewoner op de gang. Op zoek naar andere bewoners en op zoek naar ons. 'Terug naar uw kamer,' is dan de boodschap. Het is een boodschap die we mild en in beschaafde termen proberen te formuleren, maar daarin slagen we niet altijd. Omdat we haast hebben. De gepropageerde 'slow care' blijkt in coronatijden een illusie. En verder voeren we gesprekken. Over normale en bijzondere zaken. Over de dood en over doodgewone dingen:

'Waarom heeft u zo'n kleine bril op en zij daar een grote?' 'Dat is een spatbril, mevrouw De Jong. Die beschermt tegen het coronavirus.' 'Tegen welke fiets?' 'Het CORONAVIRUS.' 'O ja, daar hoorde ik gisteravond wat over op het nieuws.' 'Dat daar in het scherm van mijn telefoon, dat is uw man. U kunt nu praten.' 'Hoe is het mogelijk, jongen. Wat kun jij toch veel!'

'Denk je dat ik doodga?' 'Ben je daar bang voor?' 'Ik ben er niet bang voor, maar ik vind het gewoon mijn tijd nog niet.' 'Ik heb geen onderbroeken meer.' 'Als het goed is komen ze vandaag met de was, mevrouw Derks.' 'Dat zei u gisteren ook al, broeder.'

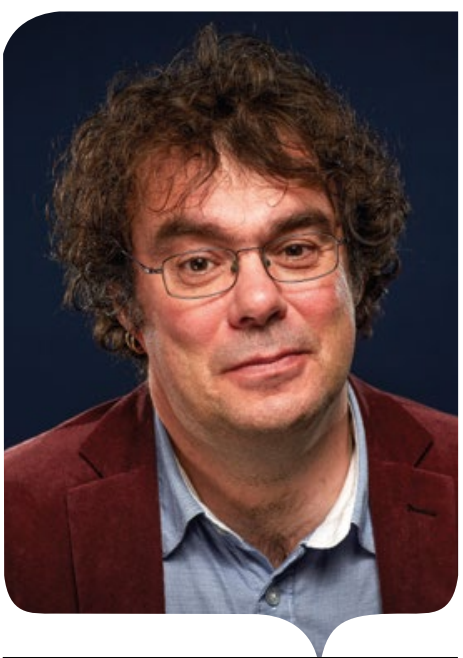

え Job van Amerongen werkt als GGZ-verpleegkundige in verpleeghuis Nieuw Vredeveld van de stichting Brentano in Amstelveen.

'Ja, ik ben me daar een haartje betoeterd. Alweer douchen? U bent zeker van de commissie hygiene! Ik blijf niet aan de gang...' 'Wanneer kan mijn vrouw weer op bezoek komen.' 'Dat weet ik niet, meneer Hoeke.' 'Hoezo weet $\mathrm{u}$ dat niet, u bepaalt dat toch?' 'Nee, dat doe ik niet. De premier bepaalt dat. Hij heet Mark Rutte.' 'Wie denkt die man wel dat hij is dat hij kan bepalen dat ik mijn vrouw niet kan zien!'
'Kunt u die wc-bril de volgende keer een beetje minder hard laten vallen? Ik schrik me dood.'

'Pastor, wat fijn dat u er bent. Zullen we samen het Ave Maria zingen?' 'Ik ben de pastor niet, ik ben de broeder.' 'Maar waarom draagt u dan een jurk?' 'Je zei een kwartier geleden ook al dat je een glas water zou brengen. Nou, het is er nog steeds niet.'

'Ik ga uw saturatie even meten.' 'Wat gaat u doen?' Uw saturatie meten. Dan weten we hoeveel zuurstof er in uw bloed aanwezig is. 'Ze kunnen tegenwoordig ook alles. Het is geweldig.' 'Verrek zeg, er staan bonbons in de ijskast. Wat lekker. Wilt u er ook eentje?' 'Heel lief van u, maar ik mag mijn mondkapje niet afdoen.' 'Wat een flauwekul, je kunt het ook gewoon zeggen als je geen chocola lust.'

'Kunt $\mathrm{u}$ iets anders opzetten dan die man met die viool?' 'Dat is André Rieu, dat is toch mooi?' 'Nou, hij komt mij hier te vaak langs met die strijkstok.'

'Dat ik niet naar de tuin mag, zei je vorige week ook al. Kom eens met een ander smoesje.'

'Als mijn been wordt ingesmeerd, moet het dan niet eerst gewassen worden? Zo wrijf je die zalf in het vuil. Dat gaat mooi ontsteken!'

'U moet wel eten en drinken, hoor.' 'En waarom moet ik dat dan wel?' 'Nou, dat is belangrijk voor uw gezondheid.' 'Als dat de reden is, vreet ik niets meer. En nooit meer.'

Het is het nieuwe normaal bij ons in Nieuw Vredeveld. Ik weet al bijna niet meer beter. 